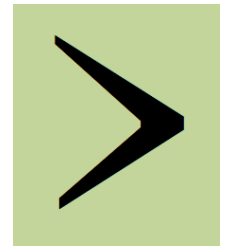

\author{
Papers in Historical Phonology \\ http://journals.ed.ac.uk/pihph \\ ISSN 2399-6714 \\ Volume 1, 187-217 \\ DOI : $10.2218 /$ pihph.1.2016.1699
}

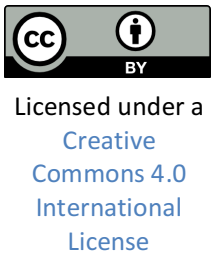

\title{
Tracing L-vocalisation in early Scots
}

\author{
Benjamin Molineaux, Joanna Kopaczyk, Warren Maguire, \\ RHONA ALCORN, VASILIOS KARAISKOS AND BETTELOU LOS \\ The University of Edinburgh
}

\begin{abstract}
This paper provides novel evidence for the frequency and spatiotemporal distribution of the earliest instances of Scots L-vocalisation. This so-called "characteristic Scots change" (McClure 1994: 48) entails the loss of coda-/l/ following back vowels, with concomitant vocalic lengthening or diphthongisation (e.g. OE healf > OSc hawff; OE bolster > OSc bouster; OE full > OSc fow, cf. Johnston 1997: 90). Using data from the Linguistic Atlas of Older Scots (LAOS), spanning 1380-1500, we reassess the claims for the emergence of L-vocalisation in the early $15^{\text {th }}$ century (Aitken \& Macafee 2002: 101-4) and for its completion by the beginning of the $16^{\text {th }}$ (cf. Stuart-Smith et al. 2006, Bann \& Corbett, 2015). Based on attestations of $<$ l>-less forms and reverse spellings, we map the spread of $<$ l>-loss over time and space. Emphasis is placed on the relative chronologies and lexical and geographic distributions of the change in different phonological contexts, including morpheme-final, pre-labial, pre-velar and (more lexically sporadic) pre-alveolar. Particular attention is also paid to the under-explored $/ 1 / \sim \emptyset$ alternation in borrowed items from (Norman) French (cf. realme reaume 'realm') and their potential influence on the development of coda-/l/ in Scots. The results show low-level presence of the phenomenon throughout our corpus, but no signs of a categorical change in any of the target contexts.
\end{abstract}

\section{Introduction}

L-vocalisation (henceforth LV) is a common feature among regional and social varieties of the Insular West Germanic languages, both historical and contemporary. In fact, it is one of the phonological changes that are deemed "characteristic" of Scots (McClure 1994: 48), representing "a persistent and vigorous feature of working-class speech" (StewartSmith et al. 2006: 77) in present-day Scotland. Why is it then important to revisit LV in the context of the earliest extant Scots documents, dating back to the fourteenth and fifteenth centuries? Firstly, the inception and operation of the change has usually been illustrated in 
reference literature with a series of stock examples, which are recycled and repeated by consecutive authors, giving the impression of a systematic, uncontroversial, across-the-board process. A close reading, however, may cast some doubt on this purported systematicity and (degree of) completion of the change in the pre-modern period. Secondly, the process has not been studied in a corpus-based fashion, which may allow emphasis on quantifiable evidence - an angle we can now provide using the FITS project database. ${ }^{1}$

\subsection{What is L-vocalisation?}

In simple terms, LV can be defined as a process by which a consonantal realisation of syllable-final /l/ - characteristically a 'dark' [1] becomes more vocalic and is perceptually recognized as a back vowel (for a discussion of the articulatory, acoustic and perceptual properties of vocalised and non-vocalised /l/, see Hall-Lew and Fix (2012)). According to Jones, this vocalic interpretation of coda [ł] is "[o]ne of the most common and historically recurrent features of English and Scots phonology" (1997: 319). Examples of LV can be found in most standard varieties, where spellings still reflect the /l/-full form, such as pre-labial LV in calf, or pre-dorsal LV in folk. Such processes are more advanced in particular social and regional accents, like Cockney and Glaswegian, where LV can be found in final position (as in coal, mole), and even following front vowels (as in milk). ${ }^{2}$

For Scots today, the process seems to be lexically driven to a large extent - $a w$ 'all' and caw 'call' make up 89\% of the LV data collected by Caroline Macafee in Glasgow in the mid-80s (Stuart-Smith et al. 2006: 74; cf. Macafee 1988, 1994). ${ }^{3}$ There are also reverse spellings with an unetymological $<\mathrm{l}>$ in several Scottish place-names, such as Kirkcaldy, Culross, Tillicoultry, creating local "shibboleths". The use of an apostrophe to mark the deleted /l/ is a frequent (if contentious) spelling convention in present-day Scots: $a$ ' 'all', $f a$ ' 'fall', $c a$ ' $d$ 'called'. Bann \& Corbett (2015: 74) include the employment of an apostrophe for a "vocalised consonant" /v/ or /l/ in their inventory of Innovative

\footnotetext{
1 'From Inglis to Scots: Mapping sounds to spelling' (FITS) is a 4-year research project on Older Scots grapho-phonology at the Angus McIntosh Centre for Historical Linguistics at the University of Edinburgh. More information on the project's website: http://www.amc.lel.ed.ac.uk/fits/.

${ }^{2}$ Note that this does not preclude such types of LV appearing in traditional "prestige" varieties. As a matter of fact, Przedlacka (2001) provides evidence for their presence in upper and middle class RP speakers.

3 The dataset collected in 1997 was very similar in this respect to the mid-80s data (Stuart-Smith et al. 2006: 77).
} 
Scots spellings of the 18th century. Similarly, inserting $<\mathrm{l}>$ as backspelling or dropping it in post-1700 texts is said to "give a visual sense of Scots" (Bann \& Corbett 2015: 65).

In this paper, we take a Scots-oriented view by narrowing the contexts for LV to the loss of /l/ after a back vowel, whereby the vowel either lengthens or forms a diphthong. As a result, we do not discuss early Scots cognates of the OE swilc-type ${ }^{4}$ or potential cases of LV after front vowels, as in milk, which is a recent development in modern Urban Scots (see Stuart-Smith et al. 2006) but not in traditional Scots varieties.

\subsection{Literature on Scots LV}

\subsubsection{Spelling evidence}

The earliest linguistic studies of Older Scots mention the interchangeability of $<\mathrm{a}, \mathrm{au}, \mathrm{aw}>$ and $<\mathrm{al}>$ in certain words, e.g. <behafe> <behalfe > (1388), <chalmer > for chamber and <walk> as a backspelling of wake (cf. Murray 1873: 122-123, Smith 1902: xxii, Girvan 1939: xlvi-xlvii). Murray calls <l $>$ in these environments "a mere orthoepic sign" (1873: 123). Later accounts also interpret $<\mathrm{l}>$ as an orthographic device to indicate vowel length and/or quality, suggesting the completion of LV and, consequently, the lack of any consonantal sound value in the grapheme. Examples in (1) show the earliest attested $<$ l>-less spellings of words with an etymological /l/ in a roughly chronological order (Slater 1952, Aitken 1977, Aitken \& Macafee 2002, Macafee 2003).

Further instances of interchangeable $<$ l>-full and $<$ l>-less spellings, such as bahuif $\sim$ balhuif, chamer $\sim$ chalmer, wapin $\sim$ wawpin, hauk $\sim$ hawlk $\sim$ hawk, faut $\sim$ fawt $\sim$ falt, lead Aitken to describe a potential "interchange under certain conditions (before $k, p, t$ ) of $a u, a w, a l$ and (before or after $b, f, m, v$ or $w$ ) of $a, a u, a w, a l$ " (Aitken 1971: 182). ${ }^{5}$ The set of environments looks far from systematic and the individual attestations are too sporadic to propose a fully operational phonological rule. Considering other instances of variant spellings in

\footnotetext{
4 Etymological /l/ was often lost in post-Conquest English dialects before "highly salient [ $\mathrm{t}]$ ]", as in OE hwylc > ME hwich, in "high-frequency words with low prosodic prominence", e.g. OE ealswa > ME as(e), and in modals should and would (Minkova 2014: 130). These types of words, however, do not show concomitant vowel lengthening or diphthongisation.

5 In their summary of LV and its impact on Scots spelling, Bann \& Corbett list a different set of consonantal contexts: " $<\mathrm{l}>$ can often be omitted after $<$ a, $\mathrm{o}>$ and before $<\mathrm{d}, \mathrm{m}, \mathrm{f}, \mathrm{k}>$ " (2015: 27).
} 
competition, Aitken proposes that there was "free variation" at play, but also "spelling tradition and scribal preferences" (1971: 186). It is therefore difficult to interpret the phonological value of the $<$ l> grapheme in sequences conducive to LV during that period. Aitken further says that: "What were 'phonemic' variants for one writer may conceivably sometimes have been merely 'orthographic' for another" (1971: 191). Thus, his assessment of the data is guarded but he does acknowledge the fact that "this series of changes did produce visible effects on OSc spelling practice" (Aitken \& Macafee 2002: 101). He also seems to suggest, however, that the retention of $<\mathrm{l}>$ in the spelling may have concealed a phonological change: the 'reduced' and 'unreduced' doublets (e.g. aw and all) "persisted at least as orthographic variants" (1971: 195) while the outcome of the phonological change can be gleaned from present-day dialects of Scots.

(1) Earliest attestations of $<$ l>-less spellings in Scots

$\begin{array}{llll}\text { a. as } & \text { 'also' } & \text { pre-1410 } \\ \text { b. auter } & \text { 'altar' } & \text { pre-1410 } & \\ \text { c. kaw } & \text { 'call' } & 1438 & \text { Ayr } \\ \text { d. Hawch } & \text { 'halch = corner, nook' } & 1457 & \text { Peebles } \\ \text { e. Auche } & \text { 'halch' } & 1457 & \text { Peebles } \\ \text { f. how } & \text { 'hole' } & 1459 & \text { north-east } \\ \text { g. Sydwawdyk } & \text { 'side'+'wall'+'dyke' } & 1462 & \text { Peebles } \\ \text { h. bauk } & \text { 'balk= beam' } & \text { late 15th century } \\ \text { i. cawk } & \text { 'chalk' } & \text { late 15th century } \\ \text { j. pow } & \text { 'pull' } & \text { late 15th century }\end{array}$

\subsubsection{Phonological environments: Affected vowels and consonantal contexts}

A summary of the operation of LV in Older Scots phonology is offered by Stuart-Smith et al. (2006: 74): "Scots l-vocalization affected /l/ in Older Scots after the short vowels /a, o, $\mathrm{u} /$ so that the outcomes of the sequences /al, ol, ul/ in West-Central Scots were respectively / $\mathrm{J}, \mathrm{u}, \Lambda \mathrm{u} /$ (cf. Macafee 1983: 38, 1994: 231) ... This process was blocked before /d/, hence $\operatorname{aul}(d)$ ('old')." In short, LV would be conditioned by the contexts preceding [ł], and those following it, as in (2).

(2) Contexts for Older Scots LV

a. following back vowels: hawff 'half', row 'roll', mowtir 'multure' 

$b$. before a pause:
fow 'full'
c. before labials:
cauf'calf'
$d$. before coronals:
haud ' 'hold', bouster 'bolster'
$e$. before dorsals:
faucon 'falcon'

In order to understand the changes to the vocalic system, it is helpful to refer to Aitken's pioneering work on the diachrony of Older Scots vowels. With an outlook to creating a stable frame of reference for the diachronically evolving phonology of Scots, Aitken proposed a system of historical vowels which foreshadowed the now-familiar English lexical sets (Wells 1983). ${ }^{7}$ Each vocalic phoneme of Scots was given a number and its development was traced diachronically (Aitken 1977, Aitken \& Macafee 2002). If we conceive of the words listed above as members of a historical vowel set, then the natural consequence of $\mathrm{LV}$ would be for these words to change into a different set as a result of lengthening or diphthongization concomitant to [1]-loss. Thus, words with a short back vowel - specifically [ư] (V19), [a] (V17), and [o] (V18) - followed by /l/, would enrich the sets of historical long back vowels - [u:] (V6), [au] (V12) and [ou] V13 - through the operation of LV (see Figures 1-3).

For the short /u/, V19, the change is essentially in quantity (Fig. 1). The other two back vowels enter a slightly more complex path as a result of LV (Figs. 2 and 3). In Aitken's interpretation, the back vowel underwent breaking because of a velarized environment, resulting "in something like $\left[a^{u}\right]$ or $\left[a^{u}\right]^{\prime}$. Here, the outcome was a fronter diphthong which merged with V12, /au/. Similarly, in the /ol/ context, the "backer diaphone of the diphthong ... merged with the existing diphthong /ou/ vowel 13" (Aitken \& Macafee 2002: 61). He argues this on the basis of the 20th-century data from the Linguistic Atlas of Scotland, for the "OSc orthographic evidence is meagre" (Aitken \& Macafee 2002: 62). Even though Aitken is rather cautious in his account of LV in Older Scots, the schematic charts exemplifying the changes in his publications have been reproduced in later scholarship without the initial caveats. It is thus important to revisit the timelines and scope of the change presented in reference literature and set them against systematically collected corpus data (see $\S \S 2-3$ below).

\footnotetext{
${ }^{6}$ In fact, haud for 'hold' is taken as an exception since, as stated above, /ld/ clusters usually block LV following [a].

${ }^{7}$ Johnston (1997) proposes a lexical-set approach for Modern Scots vowels and traces their diachronic development. For the LV contexts, the sets are: CAUGHT (Aitken's V12), OUT (V6), and LOUP (V13) (Johnston 1997: 64, 82-83, 89-90, 97-98).
} 


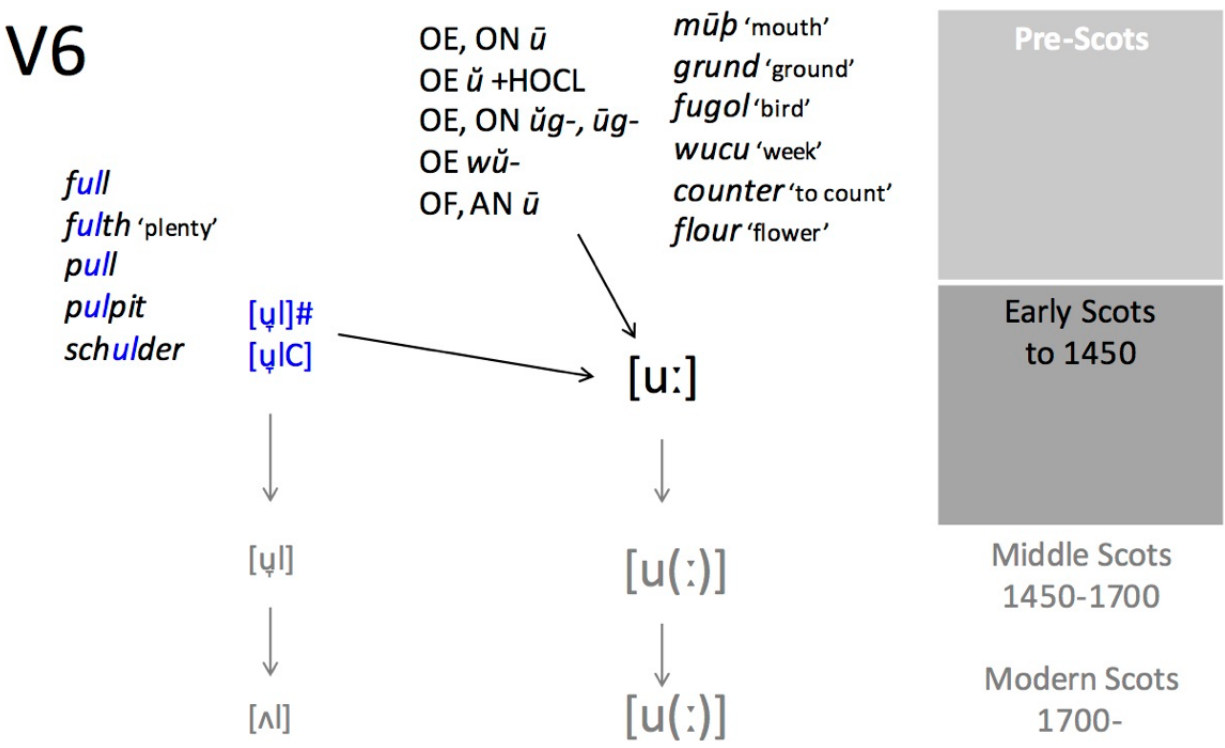

Figure 1: The diachronic development of V6 (Aitken 1977, Aitken \& Macafee 2002, Macafee 2003) and its enrichment by members of V19 set due to LV

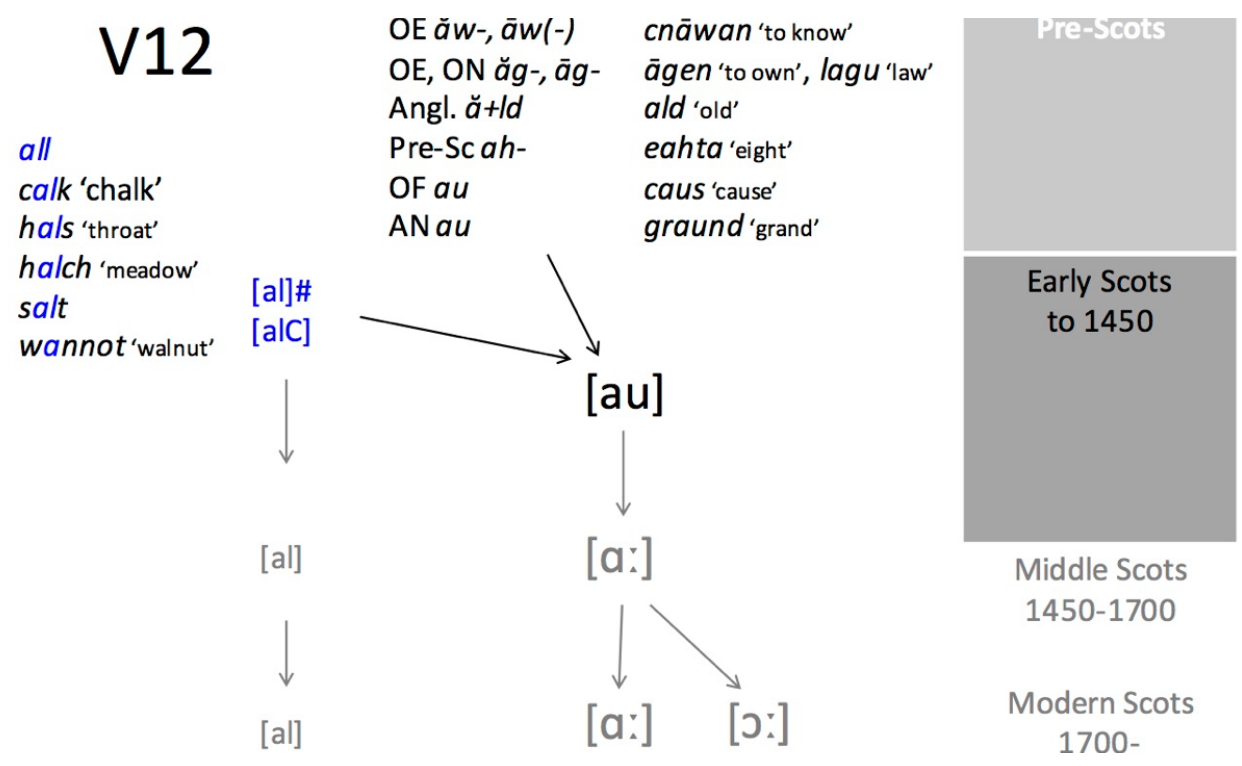

Figure 2: The diachronic development of V12 (Aitken 1977, Aitken \& Macafee 2002, Macafee 2003) and its enrichment by members of V17 set due to LV 


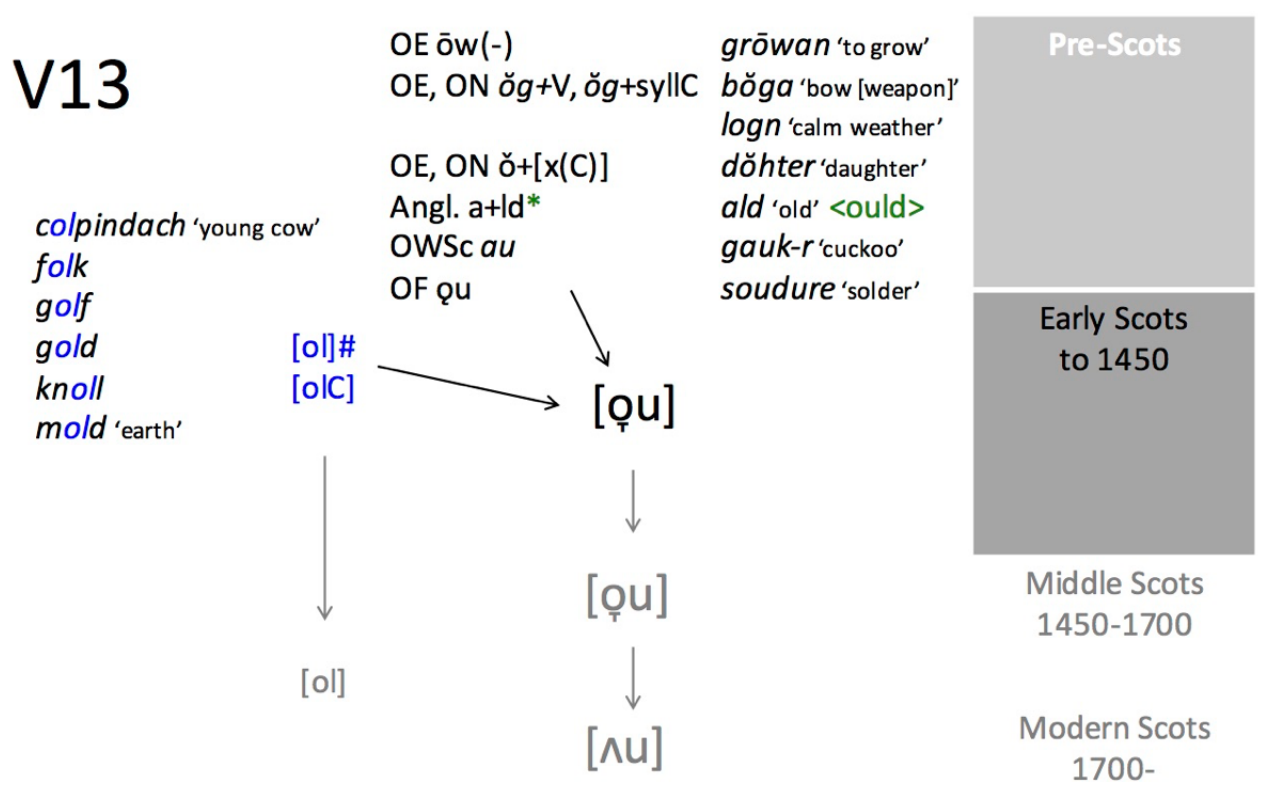

Figure 3: The diachronic development of V13 (Aitken 1977, Aitken \& Macafee 2002, Macafee 2003) and its enrichment by members of V18 set due to LV

Language contact is another aspect to consider. In terms of phonological environments, it might be the case that word-final LV was restricted to Germanic vocabulary, mostly because this environment is rare in Latin borrowings, excepting words suffixed with -al(l) (e.g. celestial, special, etc.), which never vocalize (Aitken \& Macafee 2002: 104). ${ }^{8}$ Nevertheless, borrowing from French contributed substantially to the emergence of V12 /au/ and V13 /ou/, with several Romance loanwords entering the V6 class, too. These words may also have been a product of a "[v]ocalisation of [ $\mathrm{HC}]$ clusters [which] started in OFr in the ninth century" (Minkova 2014: 131; see also Pope 1937: 154-6). Johnson (1997: 107) suggests that the Midlanders moving up to southeastern Scotland after the Norman Conquest could have brought with them a general Old English / Old Norman LV rule which in the north and in Scots became more restricted. On top of that, individual borrowings could have entered Scots vocabulary after the /l/ had been lost in the donor language. To take an example, the borrowing faut 'fault', appearing in its earliest attestation in Barbour's Bruce (1375) without the $<\mathrm{l}>$, is a product of French innovation, and its subsequent respelling as fault could have happened under the influence of Latin on Scots (either directly or via Midland dialects of Middle English). The

\footnotetext{
8 Of course, whether such endings were realised as stressed is contentious for the $15^{\text {th }}$ century, outside verse. Regarding the native vocabulary, Aitken and Macafee consider the modal verb sall 'shall' to be an exception to word-final vocalisation (2002: 104, Macafee 2003: 148, but see $\S 3$, below).
} 
etymological <l> was 'put back' by some writers between the fifteenth and seventeenth centuries. The Dictionary of the Scots Language gives examples from the second half of the 15th century: fault from Gilbert of the Haye's MS (1456) and fawlt from Peebles Burgh Records (1478). Note that <l>-less forms are earlier, which suggests backspellings rather than LV, at least for this word, in Scots.

Backspellings occur when a letter gets inserted in an unetymological context as a result of a phonological process which has modified the relationship of that letter and its original sound substance. In the case of $L V$, the sound substance of $<\mathrm{l}>$ became reduced or lost altogether, while the preceding vowel changed - it lengthened or diphthongised. Thus, the new members of the groups pronounced with V6, V12 and V13 could continue to employ <l> as an empty length or diphthongisation diacritic. This new spelling option could then spread to the original members of a given group which had never had $a<$ l $>$ or /l/. Backspellings are thus expected to be later than the inception of the change. Some examples of such backspellings in the literature are given in (3) and (4), from Murray (1873), van Buuren (1982: 62), and Aitken \& Macafee (2002: 103).

(3) Backspellings in Germanic vocabulary

a. Fallkirk $\sim$ Fawkirk 1381

b. half 'have' ?1425

c. walle 'waw, measure of weight' ?a1434

d. nolt 'nowt, cattle' (Ayr) 1437

e. haltyn hautane 'proud' 1488

f. walter 'water' 1491

g. wall 'wave' late $15^{\text {th }}$ century

h. rolpand, rolpit 'to shout, to boast' c.1515 $<$ OE hrōpan/ON raupa

i. bollis 'ox-bows' 1516

(4) Backspellings in Romance vocabulary
a. calse
'causeway' (Glasgow)
1434
b. chalmer $\sim$ chawmer 'chamber
1473
c. saulfgarde 'safeguard'
1473
d. pulder $\sim$ pouder 'powder'
1479
e. beaulte
f. salf 'beauty' $15^{\text {th }}$ century c.1515

English backspellings in the same context are earlier than those found in Scots. Minkova (2014: 131) lists several of these from the Middle English Dictionary before labials and coronals: <palcker> 
'packer' (1282), <walke> 'wake' (c.1384), <salme> 'same' (a.1399), $<$ salke > 'sake' (c.1400). For Scots, we do not have substantial written data from before 1375. Examples in (3) and (4), however, do not start immediately after continuous written record emerges, which suggests that LV could not have been in full swing before 1400. Interestingly, a quick look at the timing of the first reported backspellings in the scholarly literature shows the Romance forms in (4) to lag slightly behind the Germanic forms in (3). The use of $<\mathrm{l}>$ in unetymological contexts in these words seems to follow on from the native LV process rather than the much earlier operation of the same change in OF.

\subsubsection{Claims regarding the inception and operation of $L V$ in Scots}

Previous analyses are not unanimous regarding the placement of Scots $\mathrm{LV}$ on a timeline, and the characterisation of the change in terms of scope and systematicity remains unclear. Several scholars, for instance, make a case for its inception being traceable to the 14th-century. Girvan (1939: lxiv) finds the first occurrences in the late 14th century. On the basis of dictionary data, mainly from Robinson (1985), Johnston claims that for V6, "[c]ombinations of /uv/ and /ulC/ are realised as OUT words from early on, as the various consonant vocalisation rules are of fourteenth-century date (compare scowk for skulk; Robinson 1985: 589), or earlier [...]" (1997: 83). He continues with mergers enriching V12: "The CAUGHT class was added to in the fourteenth century, if not before, by a process inserting an epenthetic vowel between the CAT vowel and /l/ as in old [...]; <au> forms date back as far as the late 1300s [...]" (1997: 89). In turn, Macafee offers a succinct outline of LV: "A group of conditioned changes known as l-vocalisation took place in the late fourteenth or early fifteenth century" (2003: 148).

Proponents of the 15th-century operation of LV start with Murray who lists "mute l" among "obvious peculiarities" of "the Middle Period", i.e. 15 th century onwards (1873: 53). Aitken \& Macafee propose that LV emerges in the 15th century, while the earliest attestations, such as <hawhes> 'haugh, nook of land' (OE healh) in a c1240 charter from Kelso or a 1383 spelling of <hafthrepland> were "perhaps casual or idiosyncratic" (2002: 103). McClure places the occurrence of LV in "the first quarter of the fifteenth century", resulting in "a widespread use of the digraphs <al, ol $>$ and $<$ au/aw, ou/ow $>$ as free variations, in words both with and without the historical /l/" (1994: 48) [our emphasis]. In their discussion of present-day new types of LV in Glaswegian, StuartSmith et al. concede that these new pronunciations add to "an existing form of L-vocalization continued from Scots, which was completed by the mid-fifteenth century" (2006: 73) [our emphasis]. Most authors 
would thus see the change well advanced, if not completed by 1500 . Analysing the spelling and grammar in the Asloan MS (c.1515), van Buuren observes that when /l/ followed short vowels (V17, V18, V19), "it was evidently pronounced with a velar or /u/-modification" (1982: 52) [our emphasis].

Aitken (1977) captured the proposed history of all Scots vowels in a series of helpful graphs and tables, with a subtitle: "a rough historical outline". To the main inventory, he added three segments: V6a [ul], $\mathrm{V} 12 \mathrm{a}[\mathrm{al}]$ and $\mathrm{V13a}[\mathrm{ol}]$, which would merge with their respective main counterparts after the operation of LV (Table 1).

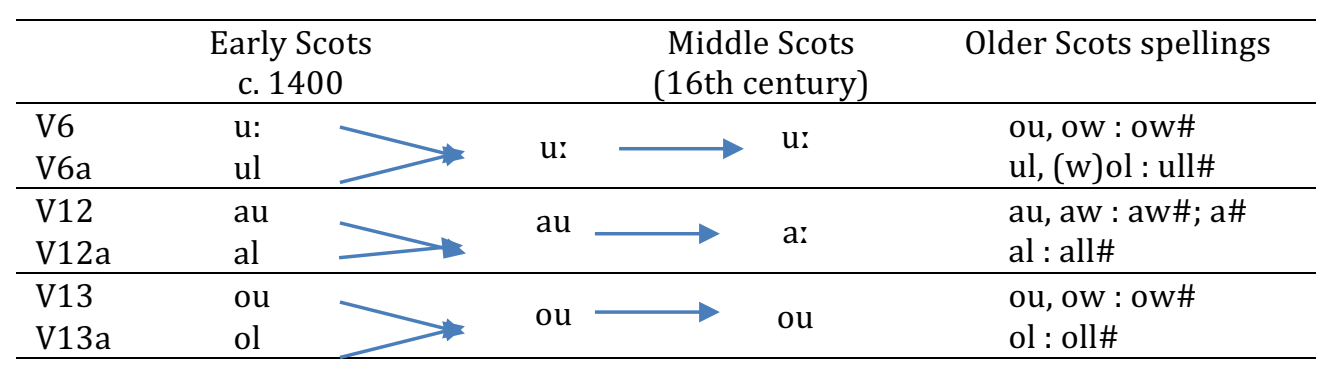

Table 1: Aitken's (1977) outline of V6, V12 and V13

\begin{tabular}{|c|c|c|c|c|c|}
\hline & $\begin{array}{c}\text { Early Scots, } \\
\text { c. } 1400\end{array}$ & $\begin{array}{l}\text { Middle Scots } \\
\text { (16th century) }\end{array}$ & $\begin{array}{l}\text { Modern } \\
\text { Scots }\end{array}$ & SVLR? & Examples \\
\hline V6 & u: & 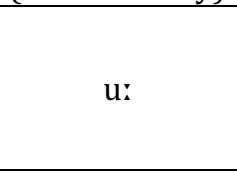 & $\mathrm{u}$ & yes & $\begin{array}{l}\text { about, mouth, loud, } \\
\text { bouk 'bulk', shouder } \\
\text { 'shoulder', hour, cow, } \\
\text { fou 'full', pou 'pull' }\end{array}$ \\
\hline V12 & $\mathrm{au}$ & $a:$ & $\begin{array}{l}\mathrm{a}: \\
\mathrm{J}\end{array}$ & $\begin{array}{l}\text { invariably } \\
\text { long, most } \\
\text { dialects } \\
\text { (cf. Aitken } \\
\text { \& Macafee } \\
\text { 2002:126) } \\
\end{array}$ & $\begin{array}{l}\text { faut 'fault', saut 'salt', } \\
\text { fraud, auld 'old', } \\
\text { mawn 'mown', cause, } \\
\text { law, snaw 'snow', aw } \\
\text { 'all, faw 'fall' }\end{array}$ \\
\hline V13 & ou & ou & $\Lambda \mathrm{u}$ & yes & $\begin{array}{l}\text { nout 'cattle', louse } \\
\text { 'loose', four, owre, } \\
\text { chow 'chew', grow } \\
\text { (and words such as } \\
\text { about, loud, house in } \\
\text { ScStE) }\end{array}$ \\
\hline
\end{tabular}

Table 2: Aitken's (1981) outline of V6, V12 and V13

Aitken probably did not consider LV to be complete in the $16^{\text {th }}$ century, since he left the vowel $+/ \mathrm{l} /$ sequences, potentially affected by $L V$, out of the tabular presentation of the Early Scots inputs to the Scottish Vowel Length Rule (SVLR, 1981: 132-133), see Table 2. He did include items affected by LV in the examples of the SVLR, though, which 
allowed him not to commit to LV being completed during a specific period.

In a recent overview of Scots spelling systems, Bann \& Corbett (2015) draw on Aitken's phonological tables, but their starting point are spelling rather than sound variants. Table 3 summarizes their rendition of the grapho-phonemic relationships between sound and spelling units affected by LV.

\begin{tabular}{|c|c|c|c|c|}
\hline \multirow{2}{*}{ OSc grapheme } & \multirow{2}{*}{$\begin{array}{l}\text { OSc pre-GVS } \\
\text { short vowel }\end{array}$} & \multirow{2}{*}{$\begin{array}{l}\text { OSc pre-GVS } \\
\text { long vowel }\end{array}$} & \multicolumn{2}{|c|}{ OSc post-GVS vowel } \\
\hline & & & SVLR-long & SVLR-short \\
\hline \multirow{2}{*}{$<$ a\#> } & \multirow[b]{2}{*}{ - } & /a:/, /ع:/ & /e:/ & /e/ \\
\hline & & $/ \mathrm{au} /, / \mathrm{al} /$ & /a:/ & $/ a /$ \\
\hline$<$ al $>$, $<$ all $>$, < aul $>$ & - & /al/ & /a:/ & /a/ \\
\hline$<\mathrm{au}>$ & - & /au/,/al/ & $/ a: /$ & $/ \mathrm{a} /$ \\
\hline$<a w>$ & - & /au/,/al/ & /a:/ & $/ \mathrm{a} /$ \\
\hline$<a w \#>$ & - & /au/, /al/ & $/ a: /$ & $/ a /$ \\
\hline \multirow{2}{*}{$<\mathrm{ol}>$} & \multirow{2}{*}{ - } & /u:/, /ul/ & $/ \mathrm{u} /$ & $/ \mathrm{u} /$ \\
\hline & & /ou/, /ol/ & /ou/ & /ou/ \\
\hline$<$ oll\#> & - & /ol/ & /ou/ & /ou/ \\
\hline \multirow{3}{*}{$<\mathrm{ou}>$} & \multirow{3}{*}{$/ \mathrm{u} /$} & /u:/, /ul/ & $/ \mathrm{u} /$ & $/ \mathrm{u} /$ \\
\hline & & /ou/,/ol/ & /ou/ & /ou/ \\
\hline & & /Eou/ & /iụu/ & /iưu/ \\
\hline$<$ oul $>$ & - & /ou/, /ol/ & /ou/ & lou/ \\
\hline \multirow{4}{*}{$<0 \mathrm{OW}>$} & \multirow{4}{*}{ - } & $/ \mathrm{u} /, / \mathrm{ul} /$ & $/ \mathrm{u} /$ & $/ \mathrm{u} /$ \\
\hline & & /y:/ & /ø:/ & $\begin{array}{c}/ \varnothing /, / \mathrm{i} /, / \mathrm{e} /, \\
/ \mathrm{I} /\end{array}$ \\
\hline & & /ou/, /ol/ & /ou/ & /ou/ \\
\hline & & /Eou/ & /iưu/ & /iụu/ \\
\hline \multirow{4}{*}{$<$ ow\#> } & \multirow{4}{*}{-} & /u:/,/ul/ & $/ \mathrm{u} /$ & $/ \mathrm{u} /$ \\
\hline & & /y:/ & /ø:/ & $\begin{array}{c}/ \varnothing /, / \mathrm{i} /, / \mathrm{e} /, \\
/ \mathrm{I} /\end{array}$ \\
\hline & & /ou/,/ol/ & /ou/ & /ou/ \\
\hline & & /Eou/ & /iưu/ & /iưu/ \\
\hline $\begin{array}{c}<\mathrm{ul}(\mathrm{l})>,<\mathrm{vl}(\mathrm{l})> \\
<\mathrm{wl}(\mathrm{l})>\end{array}$ & - & /u:/, /ul/ & $/ \mathrm{u} /$ & $/ \mathrm{u} /$ \\
\hline $\begin{array}{c}<\text { ull\#>, }<\text { vll\#> } \\
<\text { wll\#> }\end{array}$ & - & /u:/, /ul/ & /u/ & $/ \mathrm{u} /$ \\
\hline
\end{tabular}

Table 3: Older Scots $<\mathrm{a}>-,<0>-$ and $<\mathrm{u}>-$ graphemes and respective sounds in LV contexts (after Bann \& Corbett 2015: 53-56)

Not only do combinations of vowel+/l/ get listed as "vowels", on a par with their respective phonological merger targets, but also the presentation suggests an across-the-board change with no phonological or lexical restrictions. The implication seems to be that, for instance, the sequence $<$ aw $>$ could be pronounced as either /au/ or /al/ in pre-GVS 
Scots, or that the OSc word /huss/ (OE hūs 'house') could be spelled $*<$ hul(l)s $>$.

The quotations and tables presented above illustrate an important aspect of knowledge creation and transmission: through paraphrasing and summarising, initial ideas become simplified and the reader may get an impression that LV (or any other change) was systematic and completed by a certain period. Changing the mode of presentation from narrative to tabular or schematic enhances this impression. In his seminal publication, Aitken approached LV with more caution: "In certain orthographic environmental conditions and in particular words, some interchange of graphemes took place" (1977: 5). This statement is a springboard for the quantitative investigation offered below.

\section{LV in 15C Scots: A corpus-based assessment}

\subsection{Why a corpus approach?}

As we have noted, the original claims in the literature about the nature and extent of early Scots LV are ultimately unable to assess the degree to which the presence or absence of $<\mathrm{l}>$ is an artefact of the spelling or an actual feature of the phonology. Although the complex interaction of spelling representation and sound in potential LV and backspelling contexts will never allow an unambiguous interpretation, the quantification of the spelling alternants should give us important insights into the process' establishment, spread, phonological and lexical conditioning, and degree of completion.

Previous accounts, as we have seen, rely on more or less ad-hoc searches of the literature, where <l>-less spellings for etymological /l/ and unetymological <l>-insertion appear as noteworthy. In opposition, $<$ l $>$-full and $<$ l $>$-less spellings in the etymologically expected contexts are uninteresting, so they are not compiled and tend to receive no direct comment. The discrepancies in frequency can be huge, however. Aitken (1971: 199), for instance, logs the spelling <staw> for the preterit of 'steal', as a single attestation in the c.300 folios in the Scots Boece, but fails to provide a count for the prevalent <stall>-type spellings in the text.

One of the advantages of historical corpus studies is that they afford us a look not only into incoming variants, but also to their relative frequency in relation to the traditional ones. This is precisely the objective of this study in addressing the spread of LV-related spellings. Further to this key advantage, our corpus also allows us to assess the context, both linguistic (phonotactic, graphotactic, morphological, etc.) and extralinguistic (spatio-temporal), in which the different variants surface, thus providing a more nuanced picture of the process. 
Looking beyond the confines of the phenomenon of LV in Scots, a close examination of this feature is informative as regards the advantages and challenges of doing historical corpus phonology more generally. The period we are concerned with (1380-1500) is interesting because we have a fairly clear idea of the sound-system of the preceding (OE), and following (PDS) stages of the language, but can only bridge the gap by establishing plausible sound-spelling mappings based on the highly variable, non-standardised spelling system of early Scots. The result of such a study - the basis for the FITS Project described below - should allow a window into sound change spreading through language, and the changing orthographic conventions by which such sounds were represented.

\subsubsection{The corpus}

The data presented below is taken from the From Inglis to Scots (FITS) Project database, ${ }^{9}$ comprising material from some of the earliest extant non-literary texts in Scots, mostly administrative and legal documents composed in multiple locations throughout Lowland Scotland. These texts were diplomatically transcribed and semantico-grammatically tagged for the Linguistic Atlas of Older Scots 1.1 (LAOS, Williamson comp. 2008). In all, LAOS contains around 1,250 text files (c.400k words) from manuscripts of the period 1380-1500.

Resolving the relationships between sound and spelling units in the FITS database - or, grapho-phonological parsing (cf. Kopaczyk et al. forthcoming) - allows for quick targeted searches of the graphotactic and phonotactic contexts where we expect LV (and backspellings) to occur. Also, given various proposed timelines for the rise of LV in Scots, the timespan of the database is extremely well suited to test them out. The fact that locations and dates are provided for most texts affords us an even more fine-grained look at the development of this phenomenon.

\subsection{Research Questions}

The issues arising from the literature on LV in Scots lead us to propose a quantitative, corpus-based analysis of five key questions on the topic:

\section{How prevalent are <l>-less spellings in proposed LV contexts?}

\footnotetext{
9 The language variety of the corpus was originally referred to as Inglis, though it eventually came to be labelled as Scottis 'Scots' during the period represented in the corpus.
} 
The most fundamental question is whether, in the native word stock, <l>-less spellings constitute an important part of the data for the period we are concerned with, particularly if we take into account all the $<$ l $>$-full spellings in the same contexts.

2. When and where are <l>-less spellings attested?

Drawing on the fact that most of our texts are dated and localised, we contrast the timing and location of $<$ l $>$-less and $<\mathrm{l}>$ full spellings in the purported LV contexts for native words.

3. In what phonic/graphemic environments do <l>-less spellings surface?

Given that we find <l>-less spellings following all three etymologically short back vowels, we explore the contexts following the etymological $/ \mathrm{l} /$ and relate them to the rate of absence/presence of $<\mathrm{l}>$ in the spelling.

4. Does $<l>$ act as a diacritic for length/diphthongisation?

We examine backspellings as important indirect evidence for $\mathrm{LV}$, that is the presence of an $<\mathrm{l}>$ in words where it is not etymological but which share the proposed outcome vowel of LV.

5. Is the evidence for $L V$ different for Germanic and Romance vocabulary?

As words of Romance stock may have undergone LV-type processes before their borrowing (see §1.2.2), we contrast the Romance vocabulary with Germanic in terms of their proportions of $<$ l>-less and and back-spellings.

\section{Corpus-based findings}

\subsection{How prevalent are <l>-less spellings in proposed LV contexts?}

\subsubsection{Search parameters}

In order to examine the direct spelling evidence for LV in our corpus, our searches focused on lexical items with an etymological /l/ following stressed, short back vowels $[\mathrm{a}, \mathrm{o}, \mathrm{u}]$ in codas, i.e. morpheme-finally and before a consonant. ${ }^{10}$ Although LV following an etymologically long

\footnotetext{
10 An apparent candidate for this environment is the adverbial as, which is found in the FITS data predominantly without $<\mathrm{l}>$, representing etymological /l/ $<$ Anglian al(l)swa). We have excluded it from our dataset, however, as it most likely surfaced in phrasally unstressed positions (cf. fn.5).
} 
vowel is conceivable and indeed attested for later periods,11 our database shows no attestations of <l>-less spelling in such admittedly rare - contexts.

Importantly, as regards verbs, our searches included only forms in a paradigm such that the expected vowel is back. Hence for sell we included only past tense and past participle forms. Furthermore, in the cases where the expected back vowel is spelled with a grapheme which potentially represents frontness, such as <sell> for shall, we have excluded the token altogether. Finally, as the FITS database deals only with root-morphemes of Germanic origin, we report on these elements alone here. In $\S 3.5$, this data is contrasted with that from Romance vocabulary, in order to assess the potential impact of the latter on Scots LV.

\subsubsection{Search results}

The FITS database search, in line with the parameters outlined above, returned 39 root-morphemes which match the target environment, 21 of which display <l>-less spellings, as summarised in Table 4.12

Although a glance at the type-data shows well-over half of the target words displaying signs of LV, a closer look at the data for tokens shows <l>-less spellings to be far rarer than the types would suggest, being attested only 74 times across the entire corpus. As we can see in Figure 4, if we consider all potential contexts for LV, <l>-less spellings make up no more than $0.94 \%$ of the total $(7,909)$, while if we only take into account the words where <l>-less spellings are attested $(7,272)$, the proportion is only $1.02 \%$.

\footnotetext{
11 The Dictionary of the Older Scottish Tongue (www.dsl.ac.uk) does show <l>-less spellings for pool, mail, kale, scales, school, soul, foul, stool, yule from the mid-16th century onwards.

12 FITS transcription procedure captures some paleographic detail: double inverted commas stand for a trailing stroke, a plus-minus sign signifies non-continuous spelling of a root, abbreviations are expanded in parentheses, a tilde represents a horizontal line over one or more characters. Potential compounding is indicated with a set of empty parentheses preceding or following the root.
} 


\begin{tabular}{|c|c|c|c|c|}
\hline $\begin{array}{l}\text { FITS } \\
\text { morpheme }\end{array}$ & $\begin{array}{l}\mathrm{LV}+\text { or } \\
\mathrm{LV}-\end{array}$ & $\begin{array}{l}<\text { l>-full token } \\
\text { count }\end{array}$ & $\begin{array}{l}<\text { l>-less } \\
\text { token count }\end{array}$ & $<\mathrm{l}>-$ less forms \\
\hline afald 'one-fold' & + & 17 & 2 & ane" \pm favde, ane" \pm fawde \\
\hline all & + & 2255 & 5 & haw, au, aw \\
\hline almost & - & 1 & 0 & - \\
\hline alms & - & 18 & 0 & - \\
\hline also & + & 349 & 7 & assua, asua, ausua, awssa \\
\hline behalf & + & 76 & 6 & $\begin{array}{l}\text { be } \pm \text { haff, be } \pm \text { hauff, behaw, } \\
\text { behawf, behofe }\end{array}$ \\
\hline boll & + & 33 & 2 & bow, ()bov \\
\hline bolster & + & 0 & 1 & boust(er) \\
\hline bulk & - & 1 & 0 & - \\
\hline calf & + & 2 & 3 & cauf, kauf, caff(is) \\
\hline call & + & 479 & 8 & caw, kaw, cawit, kawzyt \\
\hline cold & - & 3 & 0 & - \\
\hline fall & + & 51 & 1 & tofawis \\
\hline fold & - & 11 & 0 & - \\
\hline folk & - & 18 & 0 & - \\
\hline full & + & 549 & 7 & $\begin{array}{l}\text { fow, fowely, fwfyl, } \\
\text { fuwullyt }\end{array}$ \\
\hline gold & + & 36 & 1 & gowd \\
\hline golf & - & 1 & 0 & - \\
\hline half & + & 290 & 3 & haf, haff, hawff \\
\hline hall & + & 7 & 5 & haw \\
\hline haugh & + & 4 & 1 & $\begin{array}{l}\text { hewgh } \sim \text {, hewygh } \sim, \\
\text { hawthis }\end{array}$ \\
\hline hold & + & 626 & 7 & $\begin{array}{l}\text { haud, haudyn, haudy(n), } \\
\text { hawdyn } \sim \text {, hawdy(n), } \\
\text { hawtdy(n) }\end{array}$ \\
\hline holm & - & 1 & 0 & - \\
\hline malt & + & 12 & 1 & mawyte \\
\hline old & - & 283 & 0 & - \\
\hline palm & + & 1 & 1 & pamesonday \\
\hline pull & - & 1 & 0 & - \\
\hline salt & - & 17 & 0 & - \\
\hline shall & + & 1982 & 1 & sa \\
\hline should & + & 268 & 4 & sad, sowd, sud, suid \\
\hline small & - & 11 & 0 & - \\
\hline sell vpp/vpt/aj & - & 154 & 0 & - \\
\hline stall & - & 1 & 0 & - \\
\hline stouth & - & 1 & 0 & - \\
\hline tell vpp/vpt/aj & - & 5 & 0 & - \\
\hline toll & - & 107 & 5 & $\begin{array}{l}\text { toyboith } \sim \text {, towbuth, } \\
\text { towbut }\end{array}$ \\
\hline wall & - & 21 & 0 & - \\
\hline waulk & - & 14 & 0 & - \\
\hline would & + & 128 & 3 & wad, wayd \\
\hline TOTAL & & 7835 & 74 & All tokens: 7,909 \\
\hline
\end{tabular}

Table 4: Potential LV contexts in FITS database 


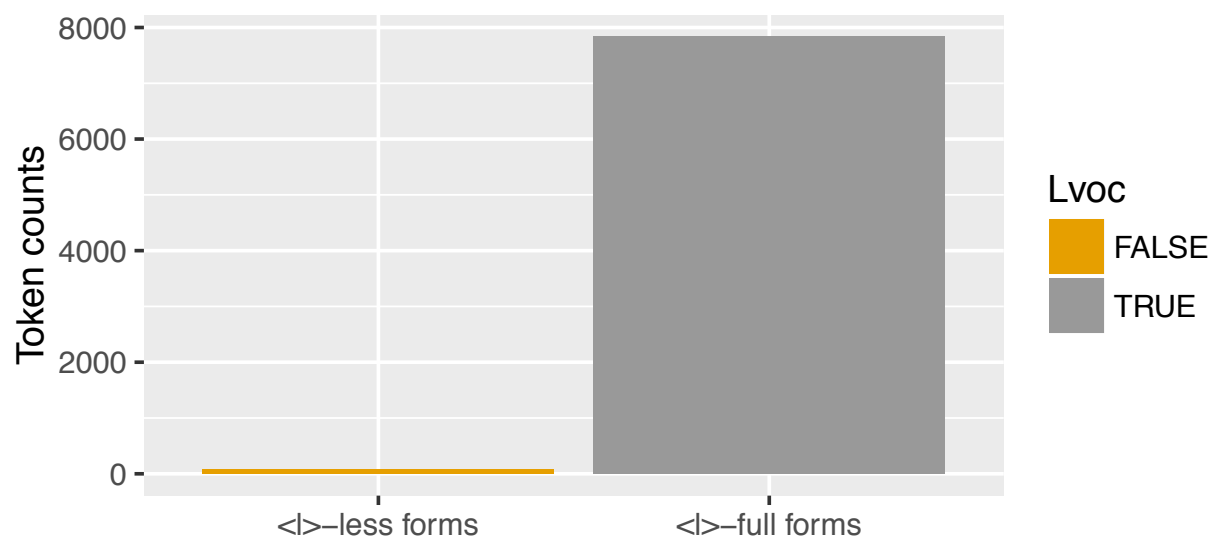

Figure 4: <l>-less vs. <l>-full spellings in all potential LV contexts of the FITS database

Turning to the distribution of $<$ l $>$-less and $<$ l>-full spellings by morpheme, Figure 5 shows that the forms suggesting LV are not the prerogative of one particularly frequent morpheme. The proportion of $<$ l>-less spellings is ultimately very low in most morphemes, while there are some infrequent items where it is more prevalent.

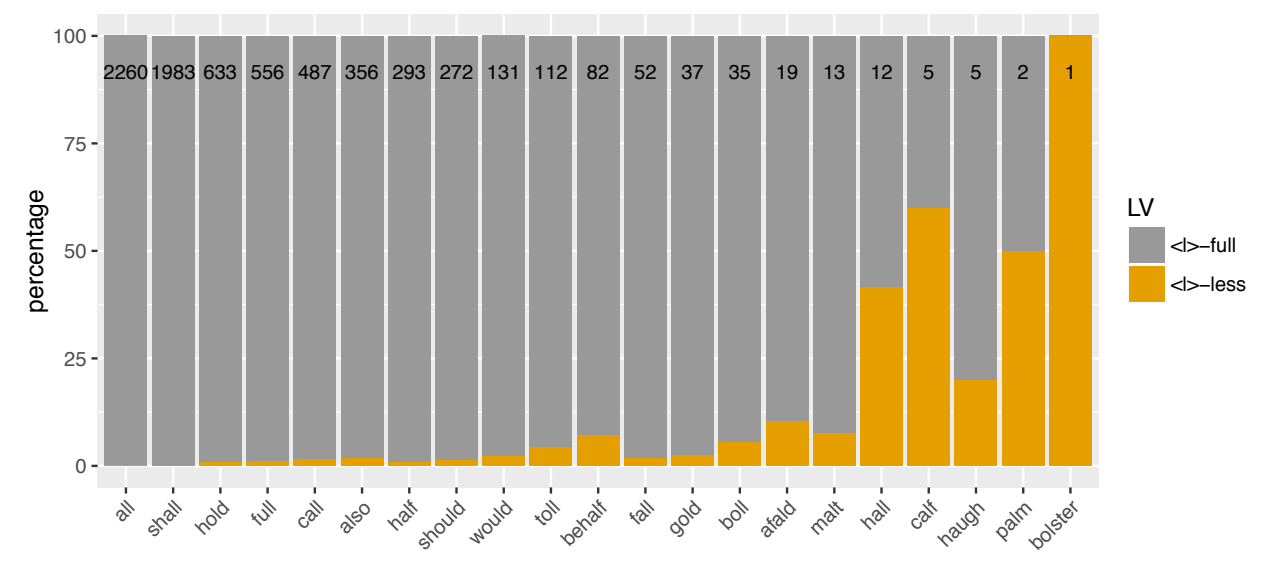

Figure 5: Relative proportions of $<\mathrm{l}>$-less and $<\mathrm{l}>$-full spellings by morpheme, with a total number of attestations for each morpheme

\subsection{When and where are <l>-less spellings attested?}

One of the major advantages of the FITS database is that the vast majority of the texts are dated and localised, due to their legal nature. That said, the problem with this record is that it is unbalanced both in 
the temporal and the spatial dimensions. In terms of the time-spread, we have a greater density of texts towards the end of the period, as records become more numerous. In terms of the regional imbalance, we find a greater density of texts in more populous or administratively important locations. Still, the geographical spread of texts is reasonable for the areas where Scots was spoken, allowing us some perspective on regional distributions.

\subsubsection{Temporal distribution}

The literature on LV seems to suggest that the period of our corpus is, roughly, the correct timeframe for /l/-loss to have taken hold or even, potentially, come to completion. With this in mind, we take a closer look at the proportions of $<$ l>-less and <l>-full spellings by decade in our corpus (Figure 6). The difference between overall frequencies in the early decades, as opposed to the later ones, is an artefact of the imbalance in the data we mentioned above. In order to make this plain, we have overlaid a temporal density line for the entire word-count of the corpus, which closely follows the overall trend for the LV contexts.

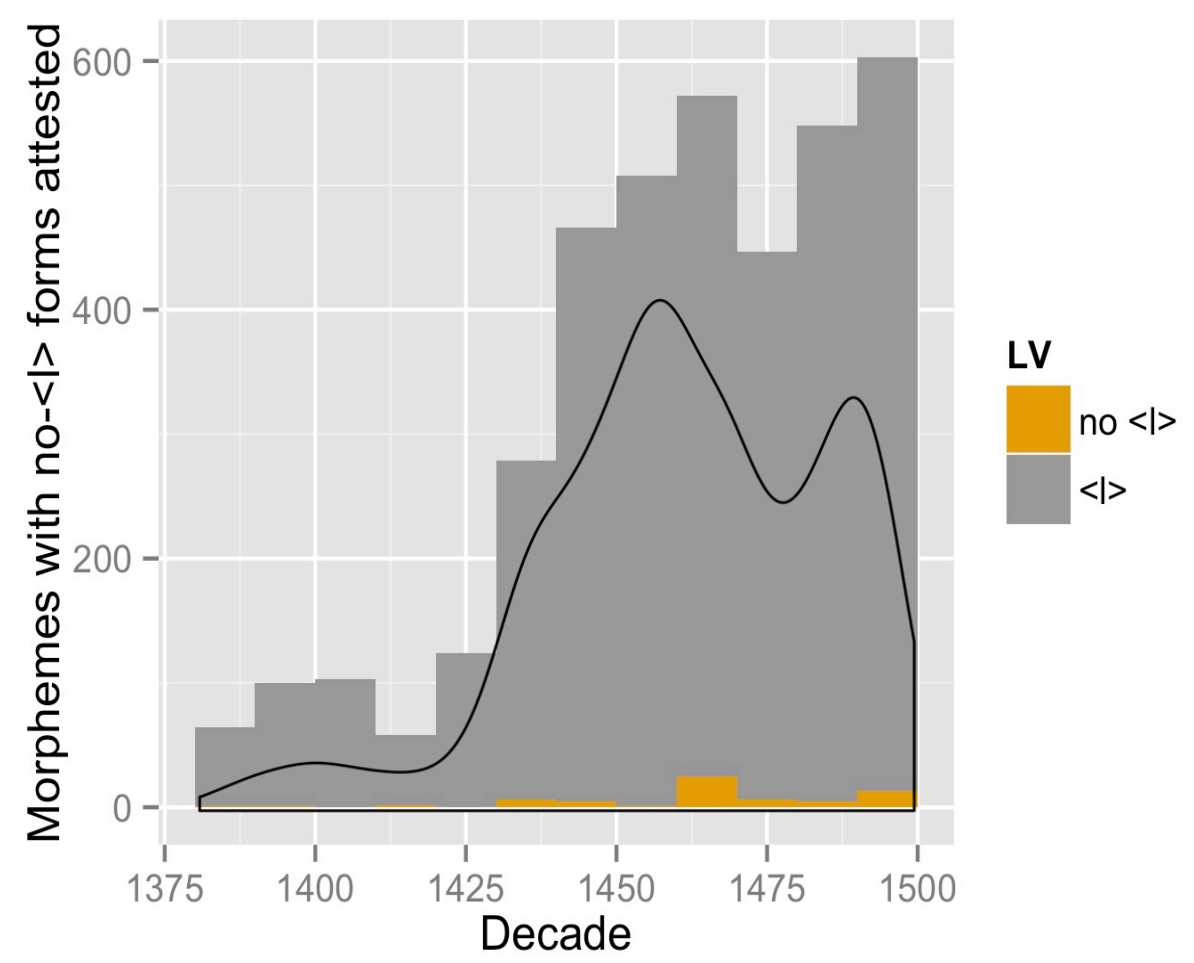

Figure 6: Distribution of <l>-full and <l>-less spellings in words with $<$ l $>$-less forms attested in the FITS corpus, by decade. The black line represents a density plot for the temporal distribution of the overall number of words in the entire corpus. 
Although $<$ l>-less attestations are rare in the corpus, they seem to follow the overall frequency trend for the corpus over time. No pattern of growth seems apparent. Rather, the evidence seems to point to LV as a constant very low-level phenomenon throughout the $15^{\text {th }}$ century, at least in the direct spelling evidence.

\subsubsection{Spatial distribution}

Since we are concerned with a feature that has been claimed to be 'characteristic' of early Scots, we try to pinpoint whether its earliest attestations in the spelling are restricted to a core area of Lowland Scotland, or whether they are more diffuse. However, the regional pattern of $<$ l $>$-less spellings, as seen in Figure 7, is not robust. This is mostly due to the fact that the $<$ l $>$-less attestations are confounded with density of texts overall.

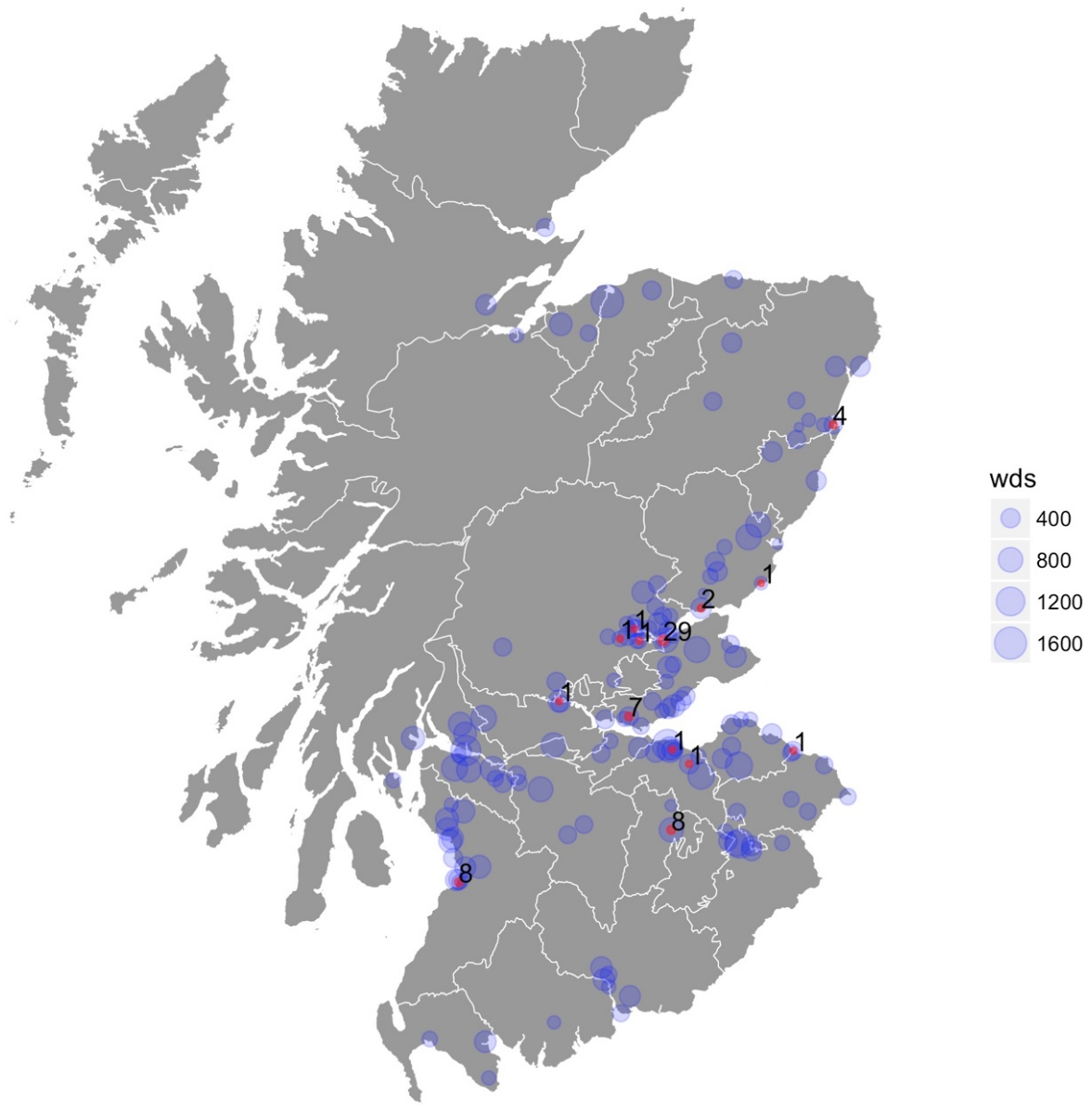

Figure 7: Spatial distribution of <l>-less spellings in view of regional coverage in the corpus: <l>-less spellings in LV contexts are given in red, with exact counts in black. The overall density of words by location are given in blue. 
Even though numbers are too low to make any strong claims, what we do see is that the largest number of <l>-less spellings are concentrated around the firths of Forth and Tay, which would have been relatively populous areas at the time. Other important foci, such as Ayr, Peebles and Aberdeen, may be showing hierarchical diffusion from one larger centre of population to another, though this remains speculative.

More interesting, perhaps, is the fact that a large proportion of the attested <l>-less spellings can be traced to 29 tokens associated to Newburgh, and dated to an eighteen-year period between 1461 and 1479. As is evidenced from the map, this particular area has a large concentration of texts overall, which might explain the propensity of these forms to a certain extent. However, temporal proximity of the texts suggests that these attestations may be the work of a single person. Still, it remains difficult to assess whether this represents an idiolect, an idiosyncratic spelling system, or a broader regional pattern.

\subsection{In what phonic or graphemic environments do $<$ l $>$-less spellings surface?}

As discussed in $§ 1.2 .2$, the literature on early Scots identifies the environments for LV as those which follow a back vowel and precede: a) a word boundary, b) a labial consonant, c) a velar consonant, or variably, d) a coronal consonant. Taking these claims as our starting point, we have organised the relevant lexical items from our corpus (cf. Table 4) into these four categories, as presented in Table 5.

\begin{tabular}{|c|c|c|c|}
\hline Final & /l/+labial & /l/+velar & /l/+coronal \\
\hline 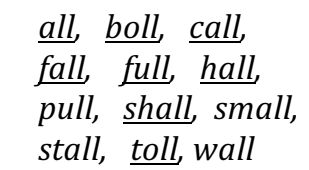 & $\begin{array}{l}\text { almost, alms, } \\
\text { behalf, calf, golf, } \\
\text { half, holm, palm }\end{array}$ & $\begin{array}{l}\text { bulk, folk, } \\
\text { haugh, } \\
\text { waulk }\end{array}$ & $\begin{array}{l}\text { afald, also, bolster, cold, } \\
\text { fold, gold, }, \text { hold, } \text {, malt, } \\
\text { old, salt, should, sold, } \\
\text { stouth, told, would }\end{array}$ \\
\hline
\end{tabular}

Table 5: FITS morphemes by grapho-phonological context fitting the LV environments. Morphemes with attested $<\mathrm{l}>$-less spellings underlined.

Looking at the word-type data alone, <l>-less spellings seem to occur in all the relevant categories, with pre-velar being far rarer than the descriptions would seem to imply, and pre-coronal being more common than expected. Examining individual tokens from a quantitative perspective, as in Figure 8, these attestations show a different pattern which, as elsewhere, seems to follow the general 
frequency of words, albeit at a very low level. No particular context is shown to be more or less conducive to LV.
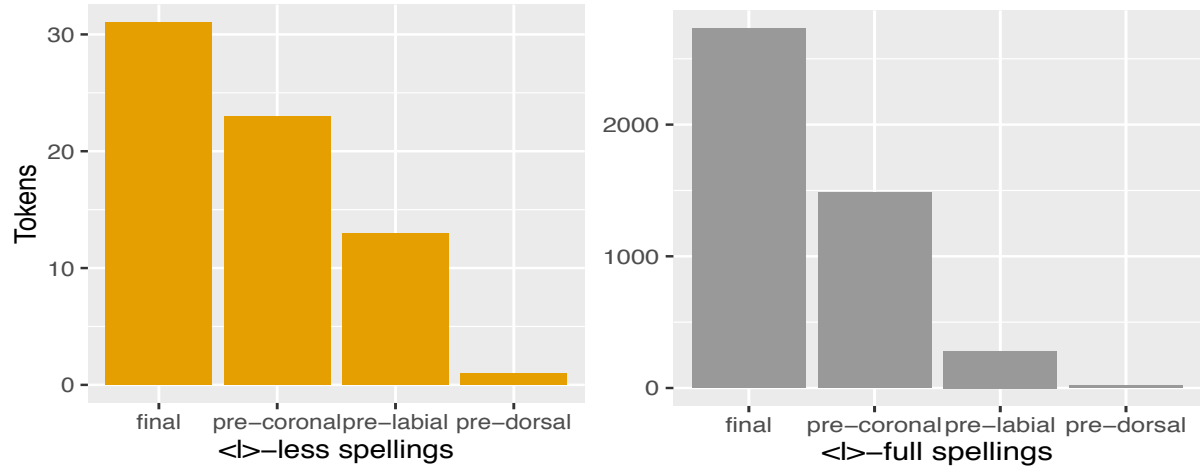

Figure 8: Attested $<$ l $>$-less and $<$ l $>$-full forms by phonological environment

Although rare, <l>-less forms in final and labial contexts are consistent with the literature. Velar contexts are extremely rare in our corpus overall (38 tokens), so having a single attested $<$ l>-less spelling (<hauthis> for Sc. haugh 'flat, alluvial land' < OE healh 'nook, corner') is unsurprising.

In pre-coronal contexts, the relatively high rate of <l>-less spellings is somewhat unexpected, given that the literature claims that $\mathrm{LV}$ did not happen after original /a/ ( $/ \mathrm{au} /$ ) and before /d/, as evidenced by cold/cauld and old/auld in Scots dialects today (Johnston 1997: 90). Still, the data in Figure 9 show that the Older Scots instances of LV closely match those attested in Modern Scots. LV is attested in also, gold, malt, should and would where it is expected. It also occurs at low levels in hold and afald. Although the first of these is clearly an exception to the rule that $\mathrm{LV}$ does not occur between $/ \mathrm{a}(\mathrm{u}) /$ and $/ \mathrm{d} /$, it is also an exception in all Modern Scots dialects, as the typical modern spelling < haud> shows. LV in afald may also be an exception, but as a morphologically complex word with stress potentially falling on the first syllable (as in English one-fold), it may be that the very small number of cases of LV in this word reflect other factors. Indeed, the two $<$ l>-less forms that are attested, have a coda nasal in of the first element, as well as a gap in the spelling (cf. <ane" favde>, <ane" fawde> vs. <afalde>), suggesting that main stress was not on the syllable with etymological /l/. In contrast to afald and hold, very frequent items such as old and sold do not show <l>-less attestations, which matches the distribution of LV in Modern Scots. 

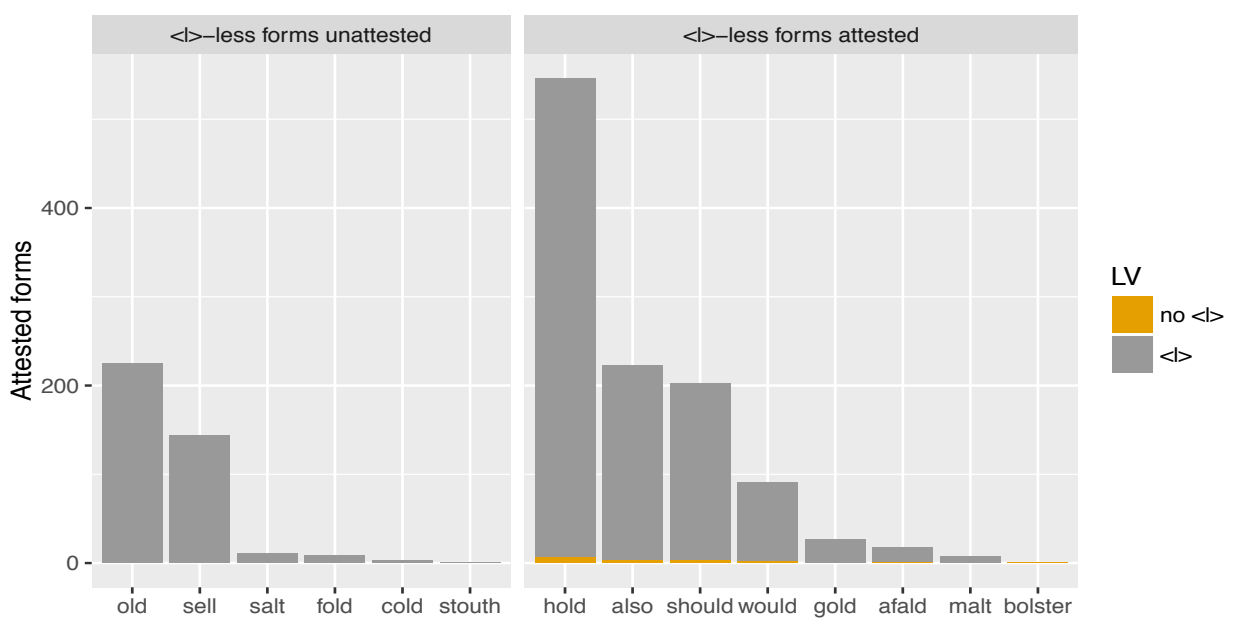

Figure 9: Comparing pre-coronal contexts

\subsection{Backspellings and the use of $<\mathrm{l}>$ as a diacritic}

While the only reasonably direct evidence for LV in the early Scots record is the non-realisation of etymological /l/ as $<\mathrm{l}>$, it is possible that the spelling system remained conservative, and kept $<\mathrm{l}>$ spellings despite its lack of phonic contents in the LV environments. The result of such a process would be the emergence of $<\mathrm{l}>$ as a diacritic for length or diphthongisation of the vowel, as discussed in $§ 1.2 .2$. We must assume, therefore, that following the operation of LV, writers would have no longer had access to any way of distinguishing the words with etymological /l/ from those without. Supposing that LV was widespread, we expect to find the use of $<\mathrm{l}>$ as a diacritic across the board in the contexts where a long or diphthongal back vowel preceded a consonant or a word boundary. If this was indeed the case, it would lend support to Murray (1873), Bann \& Corbett (2015) and other researchers in interpreting $<\mathrm{l}>$ in $\mathrm{LV}$ contexts as a marker for vowel length or diphthongisation, rather than a true lateral. As a result, spellings like <half $>$ could be taken to represent [hauf] at the level of the phonology.

\subsubsection{Search parameters}

The key environments for our backspelling searches are those where a word's etymological stressed vowel matches a proposed output vowel of LV, that is, [u:], [au] and [ou] (Atiken's V6, V12 and V13, respectively) before a consonant, or word-finally. The target root morphemes - here only for the Germanic vocabulary - were identified on the basis of the items and categories proposed by Aitken \& Macafee (2002) for the 
target vowels. These attestations were divided into two groups: those that are attested with an unetymological $<\mathrm{l}>$, and those that do not attest this feature.

Although Aitken \& Macafee (2002) note that words such as bound, found, ground and pound sometimes surface with [u:] (V6) in early Scots, in most cases they argue that the vowel was actually [ư] (V19). The FITS spelling-data makes no distinction between these two potential sounds, so we opted to follow the more frequent pattern (also consistent with present day Scots), and excluded all such forms, which furthermore display no <l>-less spellings. In the case of the word truth the FITS data does show a contrast between forms with $<$ ou $>$ and forms with <ew, ev, eu>. We include only the former types, as we take them to represent V13 [ou], while the latter types are probably instances of V14a [iu]. For daughter and trough, we only include the forms with $<$ ou > (probably V13 [ou]) as well, excluding those with < $>>$ (probably V18 [o]). We include the words weak and water, where [a:] (V4) merged with [au] (V12, cf. Aitken \& Macafee 2002: 122). To this set we also add the noun wax, which appears to have lengthened its vowel (potentially preceding [ks], as in the case of $a x$, spelled <aix > in Scots). Finally, we include forms of the word week spelled with <ou $>$ and $<0>$, representing [u:] from OE wucu with lengthening after [w] (Aitken \& Macafee, 2002:80).13

\begin{tabular}{|c|c|c|c|}
\hline V6, 12, $13+\ldots \#$ & $\begin{array}{l}\text { V6, 12, } 13 \\
\text { +labial }\end{array}$ & $\begin{array}{l}\text { V6, 12, } 13 \\
+ \text { velar }\end{array}$ & V6, 12,13 + coronal \\
\hline $\begin{array}{l}\text { bow, cow, draw, } \\
\text { ewe, know, law, } \\
\text { mauch, now, } \\
\text { owe, row, show, } \\
\text { sow, trow, waw, }\end{array}$ & dovecot & $\begin{array}{l}\text { bouk, brouk, } \\
\text { daughter, } \underline{\text { hawk }}, \\
\text { stook, } \underline{\text { own }{ }_{1}^{14}} \\
\text { trough, wax, } \\
\text { weak, week, }\end{array}$ & $\begin{array}{l}\text { aloud, brown, could, down, } \\
\text { foud, house, loose, mouth, } \\
\text { neither, nowt, sloth, south, } \\
\text { sound, town, truth, trout, } \\
\text { water, wood, }\end{array}$ \\
\hline
\end{tabular}

Table 6: Backspelling environments by phonological context. Morphemes with attested unetymological $<\mathrm{l}>$ underlined

Our search parameters yielded 43 morphemes with potential contexts for backspelling. 10 of these types showed at least one instance of unetymological $<\mathrm{l}>$, as presented in Table 6 .

\footnotetext{
13 It is not clear whether the single attestation of smolt (young salmon), spelled as $<$ smot+is > represents a case of backspelling or LV, since the word's etymology is not fully known. On these grounds, the token was excluded from our analyses.

${ }^{14}$ Among the 304 attestations of own in FITS, 112 spelling tokens seem to lack the etymological velar (<awn>, <aun>, etc.), while 189 forms imply a labio-velar approximant (<awin>, <auyn>, etc. where hiatus is unlikely). Three verbal forms imply a velar fricative: <aucht $>$, <acht $>$, <aht $>$. On this basis, we place own among velars.
} 
In the analysis of the 3,060 tokens with the target environment, a total of 24 items showed unetymological <l> spellings. Backspellings, then, make up no more than $0.78 \%$ of the potential contexts for the use of $<\mathrm{l}>$ as a diacritic. Amongst the 24 forms that do display such spellings, the most frequent morphemes are wax and week, as can be seen in Figure 10.

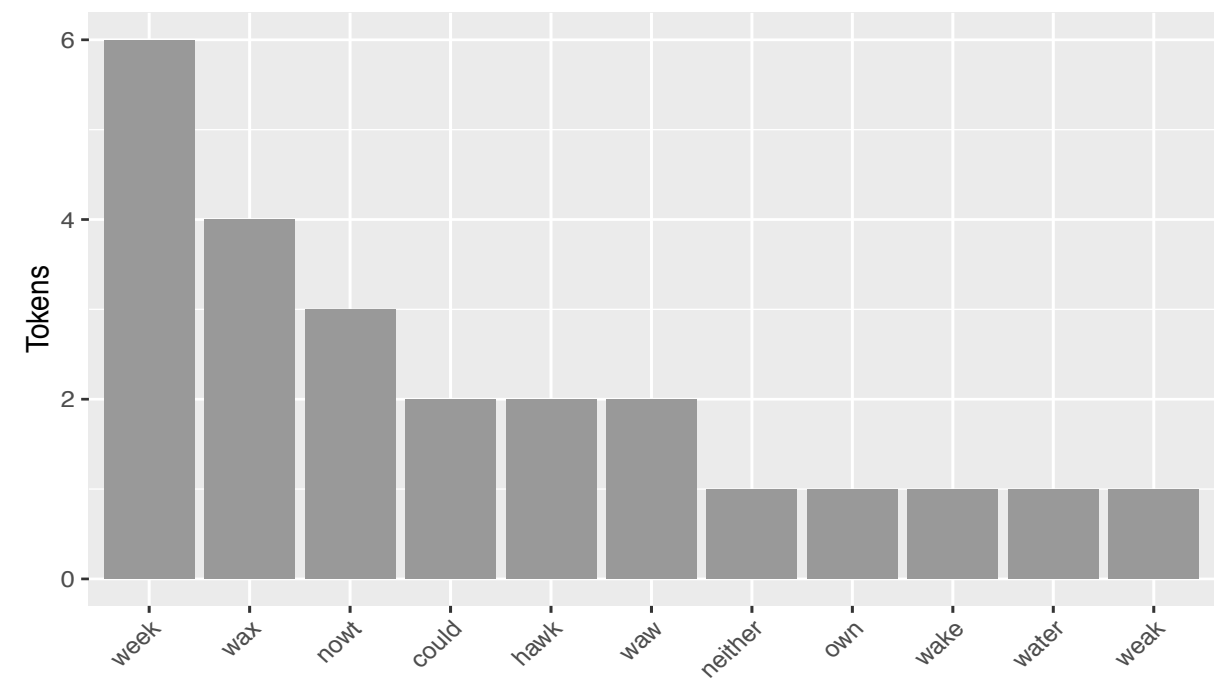

Figure 10: Backspellings: Germanic vocabulary with an unetymological $<$ l>

A closer look at the backspellings shows their strong tendency to appear with a velar element either preceding or following the target vowel. As a matter of fact, forms with velars both preceding and following the target vowel seem to be most likely to have an $<\mathrm{l}>$ in the spelling (see Fig. 11).

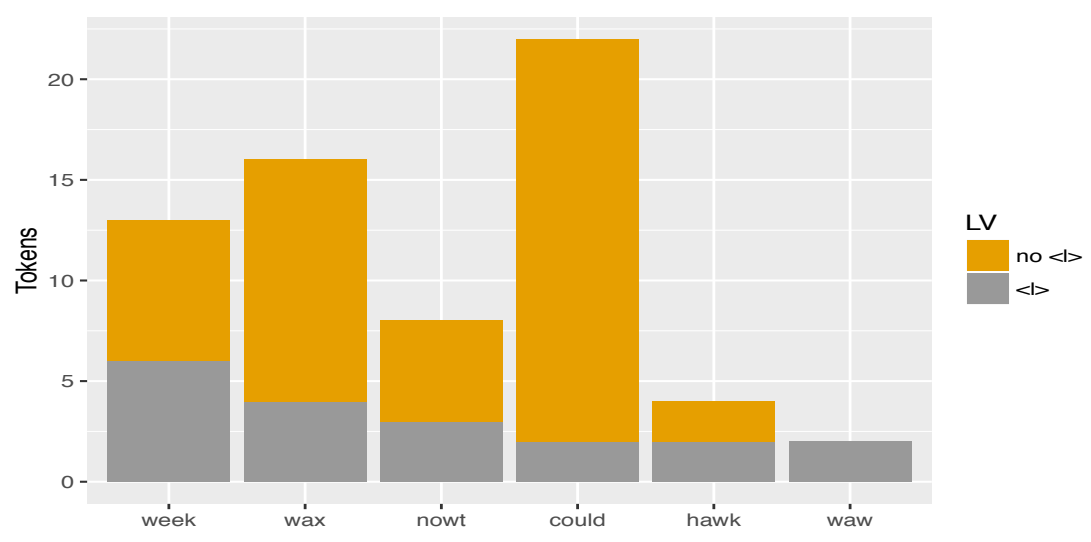

Figure 11: Proportions of unetymological $<\mathrm{l}>$ in Germanic roots

Overall, then, although velar contexts are rare in the actual LV environments of our corpus, these seem to be the most well-established contexts for LV based on the backspelling data. For the non-velar 
environments, diacritical use of $<\mathrm{l}>$ is vanishingly rare in our corpus, providing little evidence for the merger of LV outputs and existing long and diphthongal vowel categories of the period.

\subsection{Evidence for $L V$ in Romance vocabulary}

As discussed in $§ 1.2 .2$, the emergence of $\mathrm{LV}$ in Scots could be linked to the large intake of French borrowings, which, in turn display evidence of pre-consonantal [ 1 ] vocalisation during the pre-Conquest period (cf. Pope 1937:154-6). With this in mind, we examine the attestations of $<$ l>-less spellings in the FITS-database words of Romance stock with etymological $<\mathrm{l}>$. In order to complete our counterpoint examination, we survey the data for backspellings in the Romance word-stock as well.

As the FITS database excludes non-Germanic lexis, the data for Romance has been extracted directly from the LAOS corpus and subjected to the same general processes laid out above for the native vocabulary. In this case, for potential $<$ l>-less spelling contexts we have considered words plausibly stressed on a syllable with etymological /l/ in Latin, where the FITS spellings suggest a short back vowel.

\subsection{1 < l>-less spellings in Romance vocabulary}

Our survey of the Romance items with etymological back-vowels followed by /l/ in pre-consonantal and final position yielded 30 types, of which 14 display <l>-less spellings. In terms of tokens, there are 262 $<$ l>-less spellings, making up $31.4 \%$ of the 834 potential contexts for $\mathrm{LV}$.

\begin{tabular}{|c|c|c|c|}
\hline Final & /l/+labial & /l/+velar & $/ 1 /+$ coronal \\
\hline $\begin{array}{l}\text { anull, bull, } \\
\text { defoul, null, } \\
\text { roll, suppoule }\end{array}$ & $\begin{array}{l}\text { almond, aumry, } \\
\text { dissolve, } \\
\text { malvesie, realm, } \\
\text { salmon, safe }\end{array}$ & $\begin{array}{l}\text { calculate, } \\
\text { defalk, } \underline{\text { malgre }}\end{array}$ & $\begin{array}{l}\text { altar, cauldron, causey, } \\
\text { chalder, } \\
\text { lefault, false, fault, } \\
\begin{array}{l}\text { multitude, } \text { multure, penult, } \\
\text { vault }\end{array}\end{array}$ \\
\hline
\end{tabular}

Table 7: Romance items in the LAOS corpus by grapho-phonological context fitting the LV environments. Morphemes with attested <l>-less spellings underlined.

Note that a number of words would likely have had vocalised preconsonantal /l/ well before entering into Scots. To this we add the fact that the alternation between $<$ l>-less spellings and $<$ l $>$-full ones may be the result of a tradition of learned spellings based on Latin, which would have been continued by Scots scribes. In any case, some of the 
words where <l>-less spellings are attested show a fair proportion of tokens with the feature, as evidenced by Figure 12 .

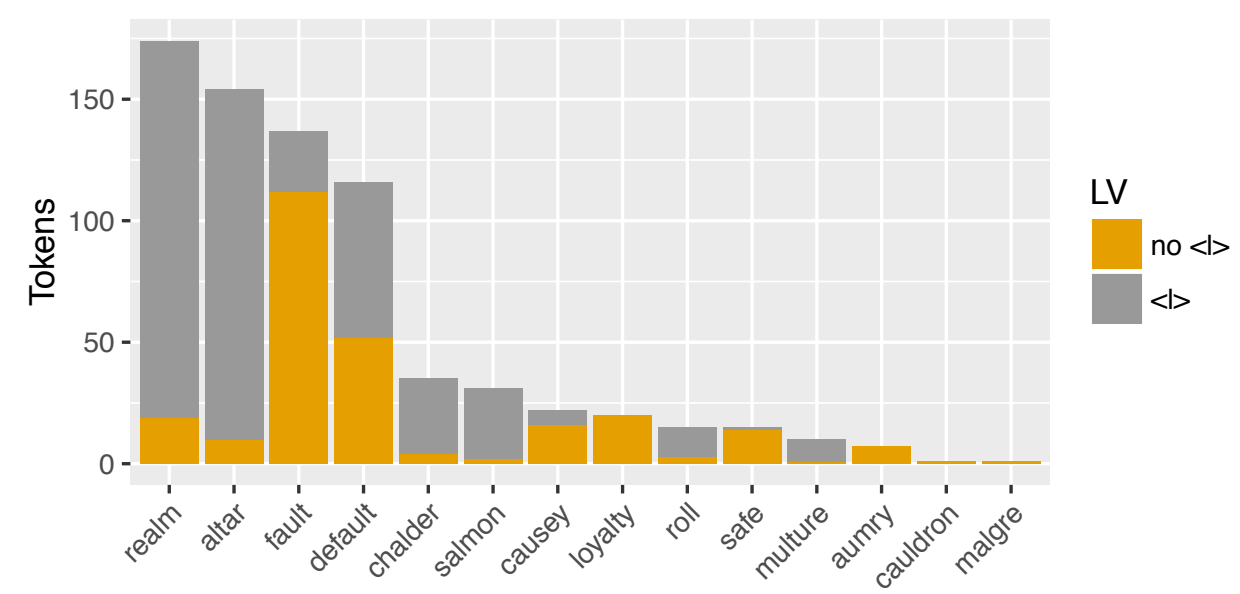

Figure 12. Romance morphemes with $<$ l $>$-less and $<$ l $>$-full spellings

This data makes plain that Romance and Germanic vocabulary do not follow the same pattern, in particular with regards to <l>-less spellings in final position. Although such forms are the most frequent in the native vocabulary, they are only attested three times for Romance, in participial forms of the verb roll (spelled <row + it $>/<$ row $+y t>$ ). The main environment for <l>-less spellings in Romance forms, in contrast, is pre-coronal, with fault, default and loyalty making up the bulk of all attestations.

\subsubsection{Backspellings in Romance vocabulary in LAOS}

Following the same procedure as for the Germanic vocabulary, we searched for instances of unetymological <l> after back vowels V6, V12 and V13, using the categories in Aitken \& Macafee (2002). Surprisingly, as we seen in Table 8, only three types display backspellings in the Romance data, amounting to no more than 18 tokens.

\begin{tabular}{llll}
\hline $\begin{array}{l}\text { LAOS } \\
\text { word }\end{array}$ & $\begin{array}{l}<\mathrm{l}>\text {-full token } \\
\text { count }\end{array}$ & $\begin{array}{l}<\text { l>-less } \\
\text { token count }\end{array}$ & $<$ <-full form \\
\hline cattle & 1 & 25 & caltal \\
\hline chamber & 3 & 6 & chalmyr, chalm(er) \\
\hline chamberlain & 14 & 40 & $\begin{array}{l}\text { chalm(er)lane }, \\
\text { chalm(er)lan+e3, } \\
\text { chalm(er)lan }\end{array}$ \\
\hline Totals & 18 & 71 &
\end{tabular}

Table 8: Backspellings: Romance vocabulary with an unetymological $<$ l $>$ 
The rarity of these 18 tokens becomes apparent when we survey all words potentially satisfying the environments for backspellings, as seen in Table 9. Since stress position in longer Romance words is somewhat contentious for this period, we have separated out monosyllables and words likely to have initial stress, from words which may have had stress on the final syllable with the target vowel. In any case, the numbers are overwhelming in comparison to those with unetymological $<\mathrm{l}>$ in Table 8.

\begin{tabular}{llll}
\hline & $\begin{array}{l}\text { Monosyllables and } \\
\text { initially stressed wds. }\end{array}$ & $\begin{array}{l}\text { Final (possibly) stressed } \\
\text { syllable }\end{array}$ & Totals \\
& $\begin{array}{l}\text { cause, croun, counsail, } \\
\text { coup, doute, grand, } \\
\text { saucer, trouble, etc. }\end{array}$ & $\begin{array}{l}\text { allow, commoun, famous, } \\
\text { merchaunt, prisoun, } \\
\text { ordinaunce, person, treason, } \\
\text { etc. }\end{array}$ & \\
\hline LAOS types & 55 & 176 & $\mathbf{2 3 1}$ \\
\hline $\begin{array}{l}\text { LAOS } \\
\text { tokens }\end{array}$ & 1995 & 5016 & $\mathbf{7 0 1 1}$ \\
\hline
\end{tabular}

Table 9: Potential contexts for backspellings (sample words with stressed vowels 6, 12 and 13) in Romance vocabulary

The data for backspellings does not support the idea that Scots used $<\mathrm{l}>$ as a diacritic for vowel length or diphthongisation in Romance words. Rather, it seems that the use of $<\mathrm{l}>$ in words which likely underwent LV in the Pre-Conquest period (such as fault, realm, causey or safe) are learned spellings, constructed on the basis of Latin (either directly in Scots or via Midlands dialects of Middle English).

\section{Conclusions}

Contrary to the generalised assumptions in the literature on Scots, our corpus study provides no evidence for the growth of LV during the 15th century. The change, though attested at a low level throughout the period, is by no means nearing completion in the spelling, nor, we contend, in the phonology. The key facts here are that <l>-less spellings make up less that $1 \%$ of the potential contexts for LV, while backspellings are only attested in $0.78 \%$ of the relevant environments.

In our corpus, <l>-less spellings are also somewhat regional, with the bulk of attestations found where population and documentary evidence is densest. Although this may represent a case of hierarchical diffusion, direct spelling evidence for LV is still too sporadic in order to make a firm claim to this effect. 
Lack of etymological coda $<\mathrm{l}>$ following back vowels seems to be a low-level variant in all target phonological environments for the Germanic morphemes. However, backspellings suggest that dorsal environments are further ahead in the establishment of the process. The $<$ l>-less spellings also suggest the final position as an important locus for LV, as compared to pre-consonantal environments, though again, this is a rather rare phenomenon overall.

With the potential exception of pre-velar contexts, there is not enough alternation in the use of $<\mathrm{l}>$ in the spelling to claim it is freely used as a diacritic. Although the argument could be made that $<$ al $>$ and $<$ ol $>$ are spellings of a long vowel [a:], as in half, and a diphthong [ə兀], as in folk in PDE, and that $<\mathrm{l}>$ has some kind of diacritic function (a 'marker' in Venetzky's 1967 terms), this is probably not the case for Scots in the period of our database. The use of $<\mathrm{l}>$ is not frequent enough in non-etymological contexts, and there aren't enough $<$ l $>$-less spellings of purportedly vocalised forms. Basically, the availability of $<$ al $>$ as a potential spelling for [au] would produce far more than $0.78 \%$ spellings of this sort in words with no etymological $<\mathrm{l}>$, due to them being undistinguishable on the surface. The lack of more forms of this type is particularly striking when we consider the amount of variation we find in a non-standardised medieval language like $15^{\text {th }}$ century Scots.

One of the generalisations that we can make is that Romance vocabulary is further advanced in the process of LV than Germanic vocabulary. This, however, can be attributed to LV in the Old French period, rather than to the incipient $14^{\text {th }} / 15^{\text {th }}$ century Scots process. The lack of interaction between the two changes finds evidence in the almost total absence of <l>-less spellings in final position for Romance forms, which contrasts with the native vocabulary of Scots, where it is the most frequent environment for LV. The lack of backspellings in the Romance word-stock, compared to the slightly better established process in native words, is another key clue to the independence of the process in the two etymological categories.

Finally, we may begin to assess whether LV can be considered a 'characteristic' feature of early Scots. From a strictly quantitative standpoint, the 'characteristic' variant in our corpus is that which preserves $<\mathrm{l}\rangle$, rather than that which loses it, at least in the spelling. Given the scanty evidence for backspellings, it is also unlikely that LV had made important inroads in the phonology of the language by 1500 . If we are to take 'characteristic' to mean simply that the attested, though rare, early Scots <l>-less and backspelled forms are unique in some way, then we must compare this data with other historically- 
related, local varieties, such as northern Middle English. Unfortunately, assessing such issues falls outside the remit of this paper.

From a methodological standpoint, our corpus approach has proved critical in allowing a view of actual counts, rather than individual albeit salient - spelling attestations in target LV-contexts. While traditional accounts may ascertain the earliest potential instances of a process of change, or describe the end-state of a development, a corpus approach is not swayed by expectations based on first attestations and later developments, allowing us a view into the progress of changes. As we have seen here, sound change need not move quickly through the grammar once begun, but may persist at a very low level rather than becoming a categorical part of the system.

\section{Comments invited}

PiHPh relies on post-publication review of the papers that it publishes. If you have any comments on this piece, please add them to its comments site. You are encouraged to consult this site after reading the paper, as there may be comments from other readers there, and replies from the author. This paper's site is here:

http://dx.doi.org/10.2218/pihph.1.2016.1699

\section{Acknowledgements}

The authors would like to thank Patrick Honeybone and Pavel Iosad, as well as the audience at the First AMC Symposium on Historical Dialectology for their feedback on previous versions of this paper. Special acknowledgements also go to Pavel Iosad for developing the $\mathrm{R}$ code allowing us to generate maps of the type presented here.

\section{Author contact details}

The FITS Team:

B. Molineaux, J. Kopaczyk, W. Maguire, R. Alcorn, V. Karaiskos and B. Los

Angus McIntosh Centre for Historical Linguistics

School of Philosophy, Psychology and Language Sciences

The University of Edinburgh

Dugald Stewart Building

3 Charles Street

Edinburgh, EH8 9AD

benjamin.molineaux@ed.ac.uk 


\section{References}

Aitken, Adam J. 1971. Variation and variety in written Middle Scots. In Adam J. Aitken, Angus McIntosh \& Hermann Pálsson (eds.) Edinburgh studies in English and Scots, 177-209. London: Longman.

Aitken, Adam J. 1977. How to pronounce Older Scots. In Adam J. Aitken, M. P. McDiarmid \& D. S. Thomson (eds.) Bards and makars: Scots language and literature mediaeval and renaissance, 1-21. Glasgow: Glasgow University Press.

Aitken, A. J. 1981. The Scottish Vowel-length Rule. In Michael Benskin \& M. L. Samuels (eds.) So meny people longages and tonges: Philological essays in Scots and medieval English presented to Angus McIntosh. Edinburgh: Edinburgh University Press. 131-157.

Aitken, A. J. \& Caroline Macafee. 2002. The Older Scots vowels: A history of the stressed vowels of Older Scots from the beginnings to the eighteenth century. Edinburgh: The Scottish Text Society.

Bann, Jennifer \& John Corbett. 2015. Spelling Scots. The orthography of literary Scots, 1700-2000. Edinburgh: Edinburgh University Press.

van Buuren, Catherine (ed.) 1982. The Buke of the Sevyne Sagis. Leiden: Leiden University Press.

Dictionary of the Scots Language. 2004. Scottish Language Dictionaries Ltd. Accessed 25 August, 2016 http://www.dsl.ac.uk/

Girvan, R. 1939. Ratis raving and other Early Scots poems on morals. The Scottish Text Society. Edinburgh \& London: William Blackwood \& Sons.

Hall-Lew, Lauren \& Sonya Fix. 2012. Perceptual coding reliability of (L)vocalization in casual speech data. Lingua 122(7): 794-809.

Johnston, Paul. 1997. Older Scots phonology and its regional variation. In Charles Jones (ed.) The Edinburgh history of the Scots language, 47-111. Edinburgh: Edinburgh University Press.

Jones, Charles. 1997. Phonology. In Charles Jones (ed.) The Edinburgh history of the Scots language, 267-334. Edinburgh: Edinburgh University Press.

Kopaczyk, Joanna, Benjamin Molineaux, Vasilios Karaiskos, Rhona Alcorn, Bettelou Los \& Warren Maguire (forthcoming) Towards a grapho-phonologically parsed corpus of medieval Scots: Database design and technical solutions.

Macafee, Caroline. 1983. Glasgow. (Varieties of English Around the World 3). Amsterdam / Philadelphia: John Benjamins.

Macafee, Caroline. 1988. Some studies in the Glasgow vernacular. Unpublished Ph.D. dissertation, University of Glasgow. 
Macafee, Caroline. 1994. Traditional dialect in the modern world: $A$ Glasgow case study. Frankfurt: Peter Lang.

Macafee, Caroline. 2003. The phonology of Older Scots (incorporating material by the late A. J. Aitken). In John Corbett, J. D. McClure \& Jane Stuart-Smith (eds.) The Edinburgh companion to Scots, 138169. Edinburgh: Edinburgh University Press.

McClure, J. D. 1994. English in Scotland. In R. W. Burchfield (ed.), The Cambridge History of the English Language, vol. 5, 23-93. Cambridge: Cambridge University Press.

Minkova, Donka. 2014. A historical phonology of English. Edinburgh: Edinburgh University Press.

Murray, James A. H. 1873. The dialect of the southern counties of Scotland: Its pronunciation, grammar, and historical relations. London: The Philological Society.

Pope, M. K. 1934. From Latin to modern French with especial consideration for Anglo-Norman. Manchester: Manchester University Press.

Przedlacka, Joanna. 2001. Estuary English and RP: Some recent findings. Studia Anglica Posnaniensia 36: 35-50.

Robinson, Mairi (ed.) 1985. The Concise Scots Dictionary. Aberdeen: Aberdeen University Press.

Slater, Jane. 1952. An edition of Early Scots texts from the beginnings to 1410, 2 vols. Unpublished dissertation. University of Edinburgh.

Smith, G. G. 1902 [1975]. Specimens of Middle Scots. Edinburgh \& London: William Blackwood \& Sons.

Stuart-Smith, Jennifer, Claire Timmins \& Fiona Tweedie. 2006. Conservation and innovation in a traditional dialect. L-vocalization in Glaswegian, English World-Wide 27(1):71-87.

Venezky, R. L. 1967. English orthography: Its graphical structure and its relation to sound. Reading Research Quarterly 2(3): 75-105.

Wells, John. 1983. Accents of English. Cambridge: Cambridge University Press.

Williamson, K. 2008. LAOS: A Linguistic Atlas of Older Scots, Phase 1: 1380-1500. Retrieved from http://www.lel.ed.ac.uk/ihd/laos1/ laos1.html. The University of Edinburgh. 